\title{
A memória em Caminho como uma casa em chamas de António Lobo Antunes
}

\author{
Memory in Caminho de uma casa em chamas by Antônio Lobo Antunes
}

Dóris Helena Soares da Silva Giacomolli ${ }^{1}$

\section{Resumo}

Esse artigo apresenta, como objetivo, refletir as concepções de tempo e suas relações com a memória no que se refere à constituição das narrativas e analisa a concepção de memória em A Memória, A História e o Esquecimento, de Paul Ricoeur, e como esta se apresenta em Caminho como uma casa em chamas, de António Lobo Antunes, bem como expõe algumas singularidades do romance através de uma revisão narrativa, baseando-se na obra de Ricoeur. Sendo a memória uma capacidade de lembrar, de guardar subsídios, indícios e vislumbres, ela é de importância fundamental para o indivíduo. Caminho como uma casa em chamas, o romance de António Lobo Antunes, forma uma conexão com o trabalho de Paul Ricoeur, quando este nos diz que lembrar-se de algo não é tão simples como somente receber uma imagem do passado, não é um ato passivo, mas ativo; o sujeito deve ir buscá-la, ativamente, sendo a memória, portanto, exercitada. Os resultados evidenciaram que Ricoeur entende a memória como uma experiência que o indivíduo tem de ressignificar ou representar; a memória se transforma em elemento primordial, é tratada e discutida na perspectiva de conferir um dever de legitimação. As lembranças são usadas durante toda narração, de um modo constante, de forma a se refletir no presente dos narradores. A memória, enquanto construção de caráter mutável e repleta de subjetividades, aparece em Caminho como uma casa em chamas como um arquivo de lembranças, intensamente marcadas, bem como de esquecimentos e vazios que podem se preencher de ruínas, rasgos de sonhos e pesadelos.

Palavras-chave: António Lobo Antunes; Caminho como uma casa em chamas; Evocações; Memória; Paul Ricoeur.

\begin{abstract}
This article presents, as an objective, to reflect the conceptions of time and its relations with memory in relation to the constitution of the narratives and analyzes the conception of memory in Paul Ricoeur's Memoir, The History and Oblivion and how it is presented on the I walk as a burning house by António Lobo Antunes, as well as exposes some of the singularities of the novel through a critical analysis based on the Ricoeur's work. Since memory is an ability to remember, to keep subsidies, clues and glimpses, it is of fundamental importance for the individual. I walk like a burning house, the novel by António Lobo Antunes forms a connection with the work of Paul Ricoeur when he says

\footnotetext{
${ }^{1}$ Doutoranda em História da Literatura - FURG e em Estudos de Literatura e História - UFPEL. Mestre em Letras e professora Estadual no Estado do Rio Grande do Sul. E-mail: dorishssg@gmail.com
} 
that remembering something is not as simple as just receiving an image of the past, it is not a passive act, but active; the subject must go to it actively, being the memory, therefore, exercised. The results showed that Ricoeur understands memory as an experience that the individual has to re-signify or represent; memory becomes a primordial element, is treated and discussed in the perspective of assigning a duty of legitimation. The memories are used throughout the narration, in a constant way, so as to reflect in the present of the narrators. Memory, as a construction of changeable character and full of subjectivities, appears on I walk like a burning house as an archive of intensely marked memories, as well as forgetfulness and emptiness that can be filled with ruins, dreams and nightmares.

Keywords: António Lobo Antunes; I walk like a house on fire. Evocations; Memory; Paul Ricoeur.

\section{Introdução}

A memória é a competência de lembrar, de arquivar subsídios, impressões e ideias e é de importância fundamental para o indivíduo. O romance está povoado de memórias; enquanto construção de caráter mutável e repleta de subjetividades, ela está intensamente marcada e é recorrente no romance Caminho como uma casa em chamas e este é o um ponto de interface com o trabalho de Paul Ricoeur, que nos diz que lembrar-se de algo não é tão simples como somente receber uma imagem do passado, não é um ato passivo, mas ativo; o sujeito deve ir buscá-la, ativamente. A memória é, portanto, exercitada.

Muitos filósofos aproximavam seus estudos do exercício da memória. Aristóteles (1986, p. 26) já dizia: "Somos aquilo que fazemos repetidamente. Excelência, portanto, não é um ato, mas um hábito". Ele costumava relacionar recordação, anamnèsis, à busca, portanto uma ação de mnèmè como afecção, pathos. A recordação seria uma busca bemsucedida. $\mathrm{O}$ autor usa os termos gregos mnèmè "ter uma lembrança" que vem passivamente e anamnèsis, recordação, "ir em busca dessa lembrança" e sua vinda ao espírito. A mnèmè, passiva vem aos personagens de Caminho como uma casa em chamas de muitas formas: por um cheiro, como veio à juíza Idália, do apartamento Segundo Esquerdo: "De manhã, ao acordar, não sei quem sou porque não conheço esse cheiro que vai do corpo aos lençóis" porque está impregnado por outro cheiro, um cheiro antigo que lhe vem às narinas "e hoje quando me perfumo sinto o cheiro por baixo" (ANTUNES, 2014, p. 29). O cheiro tem o poder de trazer o passado ao presente, numa questão de segundos. A lembrança do cheiro mistura-se ao presente, trazendo-lhe sentimentos que a 
ele se agregaram: "e eu furiosa derivado ao cheiro, esse cheiro" (ANTUNES, 2014, p. 29).

A anamnèsis, a busca, portanto uma ação de mnèmè como afecção, vem aos personagens que buscam por lembranças para afastar a solidão: "puxa a banqueta do piano e, por mais que carregue nas teclas nenhum som ou a música num lugar secreto" (ANTUNES, 2014, p. 39). Os personagens tentam trazer o passado, remexê-lo, através de sons antigos, arrastá-lo pelo pathos, como uma forma de preencher o vazio do presente. No Teeteto, Platão usa a metáfora de um bloco de cera para falar da memória - há um bloco de cera em nossas almas, presente de Mnemosine, mãe das Musas. Em cada indivíduo, o bloco de cera tem qualidades diferentes. A cera não é nem tão fluida quanto a água, que não permite reter, nem tão dura quanto o ferro, que não permite marcar. Guarda impressões por excelência. No Fedon, Platão expõe claramente a teoria das Ideias. O conhecimento da verdade e da alma consiste na recordação. Como a lógica platônica opera por modelos, aprender é recordar, re-conhecer. Memória é conhecimento da Verdade. Toda aprendizagem e todo conhecimento são uma tentativa de relembrar as realidades, as essências. Desse modo, a memória em Platão não é organizada nos termos (triviais?) da mnemotécnica, mas concebida em relação às realidades. Não é uma parte da arte da retórica. No sentido platônico, a memória - como re-conhecimento - é o trabalho fundante do todo. Diante da Razão, forma de pensar emergente, o que é a Mimesis senão sombra da sombra, cópia da cópia, aparência da aparência?!

À interrogação da lembrança sobre o desempenho da imaginação em sua construção, uma questão surge: qual a verdade da memória? Esta questão deriva da fidelidade da memória ao passado. É essa observância que torna a memória tanto autêntica quanto equivocada, na medida em que se admitem as dificuldades de sua capacidade de estabelecer o reconhecimento do passado e, então, estamos falando do esquecimento.

Toda alma decaída, por esse seu modo particular de ser, assemelhado a uma plaqueta de cera maleável, constitui-se em suporte dessa escrita primordial - mais legíveis em umas do que em outras, de acordo com as visões tidas então - podendo, por isso mesmo, ser comparada a um livro. Encontram-se gravados em cada uma delas, em caráter permanente, vestígios dos fundamentos de uma verdadeira teologia, que a atividade filosófica contínua pode fazer aflorar em sua superfície delicada e flexível. 
A memória é instável e individual, padece de inconstâncias inerentes a si.

Aqui, chega-se ao paradoxo maior da obra de Paul Ricoeur (2007). A memória, a história, o esquecimento, uma aporia traída de um conceito da filosofia de Santo Agostinho se resume em como falar em esquecimento? A memória contém o esquecimento? Se não lembrarmos o que foi esquecido, como se pode saber que algo foi esquecido? Como saber "que os judeus desapareciam depois da última esquina, do último quintal, do último cadáver e ao desaparecerem cinzas.” (ANTUNES, 2014, p. 41)?

Paul Ricoeur (2007) fala ainda de uma lembrança primária, uma retenção de um fato passado, uma memória que ainda adere ao presente, um resquício do passado que ainda ressoa na consciência; de alguma forma, ela ainda está ligada aos sentidos. Fatos antigos ligados à dor do presente:

\footnotetext{
Meus filhos adormeciam com o meu dedo na mão, se os recolhesse antes do tempo

- Estamos acordados

e hoje nem um postal me escrevem quanto mais um telefonema ou um retrato, quem sou eu para vocês, confessem, se mudava de dedo

- Não é esse é o outro (ANTUNES, 2014, p. 41).
}

Caminho como uma casa em chamas é o romance por excelência onde os reflexos do passado estão agarrados ao hoje, delimitando as ações.

Segundo Ricoeur (2007) há, ainda, a ideia de uma lembrança secundária, ou reprodução, quando o objeto desapareceu e voltou à consciência. A lembrança seria um objeto, um ato com base inteiramente na consciência; não possuiria nenhuma base na percepção. "Seu objeto deixou de ser uma lembrança, no sentido próprio da palavra, ou seja, algo retido numa relação de continuidade e de apropriação com respeito a um presente de consciência” (RICOEUR, 2007, p. 189).

Em Caminho como uma casa em chamas, há essa relação de continuidade em que o passado está mesclado ao presente, está presente na consciência, por exemplo, do bêbado que habita o apartamento primeiro esquerdo. A narração já começa imersa no passado: "O meu pai levava-me aos sábados na furgoneta de para-choques atado com arame" (ANTUNES, 2014, p. 55) que, ao desenrolar-se, mostra-se confusa. O narrador não sabe se está no passado ou no presente, vê-se menino, mas confunde-se com o pai, sem saber distinguir claramente entre os dois:

“- Não me bata pai 
convencida que é nela que bato e engana-se.” (ANTUNES, 2014, p. 59).

A lembrança seria um objeto, um ato com base inteiramente na consciência; o inquilino do primeiro esquerdo não consegue mais discernir o que era passado e presente: "Não sou capaz de traduzir isso em palavras e, se traduzisse, nenhuma pessoa entendia." (ANTUNES, 2014, p. 59-60).

O personagem não distingue mais o que apreendeu do real, o que é presente e o que é passado, tudo decompõe-se, mistura-se e fundamenta sua identidade.

\section{Memória coletiva}

Ricoeur (2007) escreve um capítulo sobre o trabalho de Maurice Halbwachs, A Memória coletiva, que se refere à memória em terceira pessoa e a ela atribui estruturas acessíveis à observação subjetiva; se torna complexificada a referência à memória coletiva da memória pessoal, enquanto se recorda de suas lembranças e, em síntese, diz que, para se lembrar, é preciso os outros. A memória deixa de ser individual; nenhuma lembrança pode coexistir isolada de um grupo social. Em Caminho como uma casa em chamas o judeu, morador do rés do chão direito rememora essas lembranças que não são só suas, mas fatos que conviveu com a família, com seu grupo social durante a fuga dos soldados de Hitler, como as memórias da "tia com um embrulhinho de roupa ou de comida nos braços" (ANTUNES, 2014, p. 71) ou de pessoas que não conheciam, mas que vivenciaram o mesmo horror: "as caminhonetas militares abandonavam o bairro na direção do caminho de ferro a distribuírem pessoas nos vagões” (ANTUNES, 2014, p. 72) e que vem a repetir-se ainda em Lisboa, durante a ditadura militar: "isso também aqui em Lisboa quase todas as noites ao adormecer quando as caminhonetas militares expulsavam um sonho que não se formou ainda.” (ANTUNES, 2014, p. 73).

As memórias de um sujeito nunca são apenas suas: a espécie de memória que é a nossa (individual) não pode, de modo algum, ser derivada desta (coletiva) e a ordem de derivação é inversa; a individual vem da coletiva. A lembrança necessita de uma comunidade afetiva, se constrói através de um convívio social que os sujeitos estabelecem com grupos sociais: 


\begin{abstract}
A palavra judeu em maiúscula na porta, os vizinhos para quem nós subitamente invisíveis e nisto as caminhonetas militares de regresso, ordens de soldados, uma descarga de pistola quando alguém fugia, centenas de baloiços com centenas de primos no chão, o oficial a aproximar-se de minha tia a tirarlhe o álbum de retratos do filho isso não vi porque nós na cave de um amigo do meu pai sempre a espreitar pela janela. (ANTUNES, 2014, p. 72, grifo nosso.)
\end{abstract}

O personagem não vê o oficial tirar o álbum de retratos que a tia segurava, mas sabe, recorda, pois a memória individual se constrói nas lembranças dos grupos nos quais esses indivíduos estiveram inseridos. A memória é sempre construída em grupos em que o homem está inserido, não importa que seja ela igreja, família, trabalho, escola, ou país: “Temos assim, acesso a acontecimentos reconstruídos para nós por outros que não nós" (RICOEUR, 2007, p. 131). As primeiras lembranças são as compartilhadas, pois, na realidade, "nunca estamos sozinhos." "Quando não fazemos mais parte do grupo de memória do qual tal lembrança se conservava, nossa própria memória se esvai por falta de apoio externo" (RICOEUR, 2007, p. 131). O homem é um ser social, dizia Aristóteles. Dessa maneira, em Caminho como uma casa em chamas, a memória do outro se insere no personagem: "pistolas com que mataram minha tia atravessou o álbum e a lembrança do meu primo atravessou-me a mim" (ANTUNES, 2014, p. 80 grifo nosso).

As lembranças do personagem estão mescladas com as lembranças coletivas, aquelas que foram lembradas, e contadas, pelo primo, pelos outros, onde se entremeiam as suas próprias. O álbum que a tia carregava, visto por ele, faz com que lembre o tiro que o perpassou, visto por outros, mas que carrega como se fosse uma lembrança própria, mesmo que se trate de acontecimentos posteriores, nos quais já não estava envolvido.

Ricoeur não concorda integralmente com Maurice Halbwachs: "Cada memória individual é um ponto de vista sobre a memória coletiva, que esse ponto de vista muda o lugar que nele ocupo e que, por sua vez, esse lugar muda segundo as relações que mantenho com outros meios" (RICOEUR, 2007, p. 133-134). Nesse complexo jogo das rememorações, pode-se dizer que não temos apenas lembranças do que vimos; não lembramos apenas o que vivenciamos, vimos, aprendemos ou ouvimos, mas também rememorações dos lugares e situações das quais aprendemos ou ouvimos algo. Mesmo aqueles que não vivenciaram, especificamente, problemas relativos à ditadura portuguesa, sentiram reflexos dela, apreenderam vivências de alguém que a vivenciou plenamente. 


\subsection{Lembranças e imagens}

Ao falar de memória, Ricoeur (2007) diz que as lembranças vêm à mente em forma de imagens, assim como a imaginação, e isso cria um laço entre memória e imaginário.

Caminho como uma casa em chamas é mais uma história de fantasmas modalizada pela memória. E a memória, como sabemos, não se materializa sem uma imagem." (FERNANDES, 2015, p. 175). Uma imagem pode fazer retornar o passado, “em Lisboa passados tantos anos, quando a minha irmã nos coloca os pratos à frente ainda nos lembramos disso e um clima de infância na sala, uma memória viva, não propriamente memória, um episódio que não desiste de nós velhos" (ANTUNES, 2014, p. 74).

O confronto entre memória e história se dará entre duas operações cognitivas e práticas; o desdobramento entre essas operações acentua a especificidade da memória, fenômeno que depende da denominação psíquica. As imagens voltam, trazendo com elas o clima do passado, "que curioso o tempo, volta e meia marcha ao contrário recuperando cenas perdidas, tardes na praia, uma girafa no carrossel que se escapou da feira." (ANTUNES, 2014, p. 75).

A imaginação tem como base o não acontecido; por sua vez, a memória dirige-se para uma experiência marcada no tempo, um fato acontecido.

Quando perguntado por Maria Augusta Silva sobre a memória que perpassa seus livros, António Lobo Antunes responde: "Não existe imaginação sem memória. A imaginação não será mais do que a forma como utilizamos a memória. Provavelmente, até o futuro é feito de memória. Porque a memória permite organizar a imaginação de maneira a viver não apenas no passado, mas também no presente e no futuro." (SILVA, 2010, p. 2).

As duas, memória a imaginação, são duas intencionalidades diferentes; nelas há pontos de afastamentos e discordâncias, sem deixar, todavia, de haver convergências que se dão a partir de que, para haver lembranças, esta se compõe de imagens. Aqui, a memória depende da imaginação, baseada em imagens, de uma composição de imagens, para que seu objeto se manifeste: "a vidraça da varanda quebrada, as floreiras do muro do chão, os pneus do automóvel furados" (ANTUNES, 2014, p. 75). 


\subsection{Rasto e esquecimento}

O que a noção de rasto e esquecimento tem em comum é, antes de tudo o mais, a noção de apagamento, de destruição: "nenhuma fotografia, nenhum reposteiro" (ANTUNES, 2014, p. 36). Mas este processo inevitável de apagamento não esgota o problema do esquecimento. $\mathrm{O}$ esquecimento tem, igualmente, um polo ativo ligado ao processo de rememoração: "evito pensar em ti e continuas a aparecer-me." (ANTUNES, 2014, p. 50). Podemos dizer que a busca para reencontrar as memórias perdidas, que, embora tornadas indisponíveis, não estão realmente desaparecidas, são "restos de coisas que juntava sem pensar como eu restos de coisas que juntava sem pensar, fuzilamentos, explosão, quedas não mencionando a memória que se apaga” (ANTUNES, 2014, p. 81).

Agarrando-se à memória, mesmo quando ela não existe mais: "perdi as datas uma a uma" (ANTUNES, 2014, p. 79).

Caminho como uma casa em chamas é um romance da memória repleto de lembranças, de esquecimentos e vazios que podem se preencher de ruínas, rasgos de sonhos e pesadelos: "Os personagens puxam pela memória sem querer que ela volte, a rememorar acontecimentos dos quais não querem uma lembrança exata: "não tenho certeza, tenho a certeza, não desejo ter a certeza e, por conseguinte enganei-me". (ANTUNES, 2014, p. 270) Os rastros permanecem numa luta contra o esquecimento, seguem nas memórias daqueles que vêm continuar a voz narrativa, os novos narradores dos últimos capítulos de cada narrativa, continuadores da memória dos que morreram ou dos que se cansaram de narrá-las.

\section{António de Oliveira Salazar e a ditadura em Portugal}

Ditador que esteve à frente de Portugal de 1926 a 1968, fazia discursos em que pretendia igualar a todos:

Em vez de elevar o povo ao máximo, os discursos mostram ao povo que é ele, embaixo na escala social, que tem valor. A humildade, a pobreza, a caridade são outras tantas virtudes que constituem o pano de fundo da exaltação da Pátria como valor inatacável, fundado, enraizado nos grandes valores do passado (MENÉNDEZ, 2009, p. 1).

Em um discurso de 26 de maio de 1936, Salazar, nascido em uma família humilde de pequenos proprietários agrícolas ("sou um filho do povo"), exalta o pobre, o 
trabalhador, o agricultor que deseja manter sua vida comum, sua paz e seu pedaço de terra: apelava para os desejos mais profundos do povo:

\begin{abstract}
A vida é áspera, há desgostos, angústias, privações, injustiças que parece ninguém pode reparar. Um ambiente de carinho, porém, envolve o lar e uma luz superior ilumina a existência: a velha igreja e o seu adro foram feitos a expensas de todos os vizinhos, com esmolas e trabalho; o cemitério também. Numa parte e noutra há verdadeiramente o suor do rosto, a preocupação de viver, a tradição do sangue, o património moral. Do fundo das consciências surgem claramente estes imperativos: o trabalho na vida, a propriedade na terra, a virtude na família, a esperança nas almas. [...] Mas o homem na vida doméstica, no trabalho, na Nação, é obrigado a organizar a sua ordem. Devido ao desequilíbrio do espírito humano, a ordem não é espontânea: é preciso que alguém mande em benefício de todos e que se procure para mandar quem possa mandar melhor (MENÉNDEZ, 2009, p. 4-5, grifo nosso).
\end{abstract}

Depois de uma ditadura de quarenta anos, em que soube manipular os valores e a confiança de todo um povo, é natural que ainda se ouçam gritos de "Salazar, Salazar, Salazar! "(ANTUNES, 2014, p. 22), voz de um anônimo que se espalha pelo livro, voz do povo que se ouve logo no início do texto de Lobo Antunes e uma voz que o defendesse: "Salazar não foi um ditador, [...] foi um patriota que pôs esse país na ordem, em Portugal precisamos de um governo firme" (ANTUNES, 2014, p. 15 ). Quando um Salazar cansado, recusa-se a continuar governando, se esgueira e procura um lugar onde possa se esconder: “-Existirá um sótão livre nesta?” (ANTUNES, 2014, p. 347).

A ditadura de Salazar deixou marcas no inconsciente coletivo, afinal "mais de quarenta anos num sótão a governar em segredo deixam marcas na gente" (ANTUNES, 2014). Ele mostra essas marcas na sua escritura: "Qualquer estreita relação com um memorial ficcional das mentalidades portuguesas faz deste romance a actualização de uma questão ainda latente". (FERNANDES, 2015, p. 177).

Salazar defendia valores tradicionais católicos dos camponeses. Falava de si próprio como filho de família pobre de agricultores e baseava-se no populismo. A ditadura de Salazar é apreendida na obra de António Lobo Antunes através de vozes ocultas que o louvavam, entrecortadas por vozes oprimidas dos personagens que o temiam e que mostram as violências sofridas:

"Como é Salazar, senhor professor?

e ele, mirando por cima de nós numa gravidade emocionada, 
- Um gigante". (ANTUNES, 2014, p. 22).

A ditadura portuguesa aparece vista pelos olhos do outro, do admirador, vozes que chegavam de um passado mais antigo: "Salazar não foi um ditador [...] foi um patriota que pôs esse país na ordem, em Portugal precisamos de um governo firme" (ANTUNES, 2014, p. 15) ou lembranças da infância: "Uma ocasião em estudante a polícia prendeu a minha cunhada dois dias, exibiram-lhe páginas policopiadas, jornalecos, cartas,

- Você pertence ao partido?” (ANTUNES, 2014, p. 33).

Salazar e a ditadura e as guerras coloniais aparecem no romance como apagadores de vontades e memórias, do

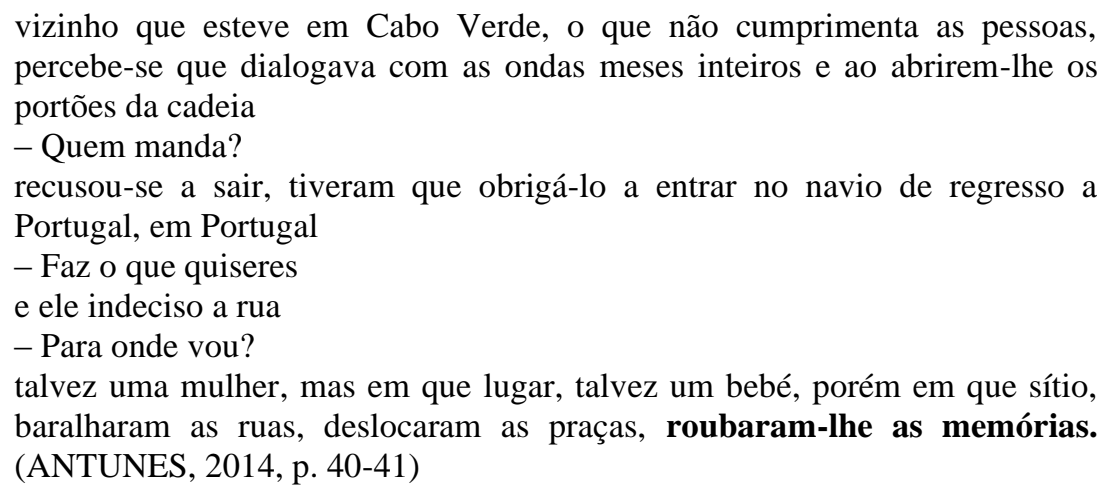

Não há como um extenso período de um governo ditador não ter deixado marca na memória e na identidade dos habitantes de Portugal, formando imagens que se contradiziam: "Salazar sacrificava-se pela gente [...] se não fosse Salazar, Portugal na miséria ou uma província da Espanha e a gente a pedir esmola na rua" (ANTUNES, 2014, p. 62). Na forma de metáfora, nos habitantes do prédio que, "à medida que a tropa ia e vinha nas ruas e a polícia espiava a cidade, mesmo em Lisboa agora que tudo acabou" (ANTUNES, 2014, p. 45) continuavam a caminhar "como uma casa em chamas.

\section{As narrativas}

Assim António Lobo Antunes descreve como surgiu Caminho como uma casa em chamas em sua imaginação: 
Era o início do livro, mas ainda não era o livro. Desenhei mais quatro ou cinco casas, com inquilinos de um lado e do outro, até ao quarto andar. A seguir entendi que lhe faltava o sótão e desenhei o sótão. Depois, a pouco e pouco, os diversos apartamentos foram sendo habitados. Depois, a pouco e pouco, os habitantes principiaram a mudar (ANTUNES, Entrevista, 2012, s/n)

E assim termina o romance: "Sobre as tábuas de andaime em que o fogo custa a pegar de um prédio demolido" (ANTUNES, 2014, p. 357). A narrativa feita em capítulos obedece a uma ordem sequencial que não exerce controle no sentido das narrativas ou do romance. Do começo ao final é um queimar, um arder de chamas; os personagens, desorientados pelas memórias, incendeiam-se. Nele, os narradores fazem emergir o passado, trazendo vários tempos da memória em um tom subjetivo que se revelam pelo clima de rememoração e nomeadamente porque são fluxos de consciência que se percebe na voz de todos os personagens.

As narrativas contemporâneas poderiam muito bem ser lidas como contos, aleatórios, sem que isso lhes acrescentasse ou enfraquecesse os conflitos, a coesão, as tensões e a coerência. São chamas que se avolumam e minguam conforme a força da memória que vem aos personagens. Nas narrativas não há convenções, não há os tradicionais conflito, clímax e desenlace, e isso não faz falta ao leitor que consegue depreender deles essas combinações.

\subsection{O título}

Como caminharia uma casa que está em chamas? Quais sentimentos a impeliriam a caminhar, mesmo estando a queimar, a arder? Seria desespero, angústia, desejo de fuga, de esquecimento? "Caminhar como uma casa em chamas significa, talvez, perder a própria noção de espaço-tempo que toda uma geração pode ter despercebido ao dissipar as próprias percepções sensoriais ou fantasmáticas” (FERNANDES, 2015, p. 174).

O título do romance, Caminho como uma casa em chamas, se repete na fala de todos os enunciadores. Esse caminhar, que é dos personagens, dos habitantes do prédio, é um caminho de aflição, é o caminhar da narrativa; casa que caminha num estado de inconsciência, que vai alterada, pelas ruas, pelos campos, alterada, cega pela fumaça, asfixiada, desorientada, acompanhada pelo medo. 
Por isso, está longe de ser tão-somente a repetição de temas recalcados. Esta ficção convoca fantasmas da memória portuguesa de quase um século e acaba por apontar uma realidade recheada de silenciamentos em que figura a projecção de um Salazar espectal. Neste livro sobre a passagem do tempo e a cristalização das coisas, cabem os fantasmas de um país. Mas, apesar de darem conta de um passado relativamente próximo, a percepção pertence ao presente. Através de uma complexa sobreposição de tempos e espaços, coexiste debaixo do mesmo telhado aquilo que há de mais secreto em cada personagem (FERNANDES, 2015, p. 177).

Caminhar, caminhar depois de uma ditadura de quarenta anos. Achar um caminho novo depois que o anterior já estava marcado por sulcos de quatro décadas, conhecidos, seguir caminhando um caminho titubeante, vacilante, incerto diante das dimensões novas, como os negros libertos que saíram a caminhar hesitantes pelas estradas depois da escravidão de tantos anos. Onde ir? Como se acostumar à renovação do ar; ao novo libertador que ocupava o lugar do velho conhecido, mas em estado de decomposição, com cheiro de ranço e gosto acre? Não é fácil continuar a caminhar, marcado pelo antigo que continua a arder, quando as chamas teimam em não se apagar. Mas quem disse que a vida é fácil? Quem disse que “a vida é uma sorte e peras?” (ANTUNES, 2014, p. 90).

\subsection{O edifício}

O prédio é um espaço habitado por personagens que carregam fortes relações com a Memória. No que se refere à constituição de narrativas, se compõe para além de um ambiente físico; é, principalmente, sítio de múltiplas, e doloridas, vivências.

Além da referência a uma casa no título, o que chama a atenção, numa primeira leitura, é a arquitetura do romance, que se constrói como uma casa, ou melhor, como um prédio de apartamentos de quatro andares e mais o sótão. Cada andar do edifício abriga dois apartamentos; em cada andar vivem os personagens, pessoas que se conhecem, que se misturam em suas vivências, que se refletem nas vidas uns dos outros, que conhecem, mesmo de relance, a dor um dos outros. No continuum da leitura, vamos conhecendo, ou adivinhando, os moradores através de suas memórias, bem como também podemos ir entrando em contato com os outros moradores através de relances, falas e rasgos de informação que escapam e se entrecruzam na fala dos narradores, dos moradores do prédio que representam os moradores de Portugal. De fato, o prédio poderia ser considerado parte de um todo, conforme a estrofe de Gregório de Matos "O todo sem a parte não é todo / A parte sem o todo não é parte / Mas se a parte o faz todo, sendo parte, 
/ Não se diga, que é parte, sendo todo." O prédio é a parte de um todo, representa uma nação, é Portugal sobrevivente da ditadura, é o universo português.

Os nomes dos capítulos são as localizações dos apartamentos e, a partir deles, se dão as narrativas; são referências às localizações dos moradores que ali vivem: Rés do Chão Direito, Rés do Chão Esquerdo, Primeiro Direito, Primeiro Esquerdo, Segundo Direito, Segundo Esquerdo, Terceiro Esquerdo, Terceiro Direito e sótão. As memórias dos personagens se repetem três vezes, sempre na mesma ordem, têm extensão semelhante, apesar de que seus narradores nem sempre se mantenham.

O edifício se constrói de escritura, a começar pela própria consciência dos personagens-enunciadores, que declaram, aqui e ali, estar escrevendo: "E agora que meu padrasto já cá não está apetece-me escrever-lhe eu que não escrevo a ninguém" (ANTUNES, 2014, p. 98).

\subsection{Os personagens}

Os personagens reverberam acontecimentos políticos e os misturam aos próprios problemas que neles residem, embaralhadas com as lascas, os fragmentos, as saudades, os estilhaços e as dores de suas próprias vidas. Os personagens de Caminho como uma casa em chamas trazem em si essas recordações que vêm tanto passiva quanto ativamente e eles as carregam como paisagens interiores, terra arrasada dentro de si.

O passado volta mil vezes aos personagens de Caminho como uma casa em chamas, passivo, mas corrosivo; o lembrar-se difere de fazer algo, pois não há o que mudar nessa paisagem de devastação interna. O filósofo Paul Ricoeur (2007) distingue a problemática do esquecimento em duas figuras gerais: o esquecimento por apagamento de rastros e o esquecimento de reserva, que implica num esquecimento total e na ideia de inesquecível, respectivamente. $\mathrm{O}$ autor ainda trata do esquecimento manifesto, isto é, de uma pragmática do esquecimento. Se o esquecimento manifesto é também um esquecimento exercido, ele pode ser analisado à luz dos "usos e abusos da memória", do "dever de memória" e da sua confiabilidade, uma vez que, em nome dela, ocorrem exercícios de apagamento e omissão, ao mesmo tempo em que invenção e imposição. "O esquecimento é o emblema de quão vulnerável é nossa condição histórica" (RICOEUR, 2007, p. 300). 
Há esquecimento onde houve marca, por isso se relaciona com a memória e a fidelidade ao passado, sendo seu polo oposto. O esquecido não é só o inimigo da memória e da história, há uma figura positiva do esquecido, o "esquecido de reserva", que constitui um recurso irredutível e "reversível” a qualquer balanço de fiabilidade com o passado, por meio da memória ou da história. É uma existência inconsciente do recordar-se que pode reaparecer com a força da impressão original e que atesta nossa persistência na existência.

Não há reconciliação com esse passado onde se remexem os escombros como dores, gemidos e lamentos. A memória surge em Caminho como uma casa em chamas como um arquivo de lembranças, "episódios chegados à tona em bolhas que se desfazem para nascerem de novo no fundo da lembrança procurando o seu caminho" (ANTUNES, 2014, p. 105). Os personagens são construídos em cima “dessa solidão empenhada sobre o papel que olha para nós e diz-nos o que precisamos ouvir, o que não sabemos exprimir, as vontades ausentes de um tempo esquecido na "fininha melancolia" que tantas vezes nos abraça" (ANTUNES, Biografia, 2014, p. 1). Essa fininha melancolia, na maior parte das vezes, transforma-se em melancolia funda, profunda, grossa, dolorida. Essa transformação nos é mostrada por um fluxo de consciência que traz à tona horrores íntimos, aterradores, de memórias que se guarda, que não se conta, que se reprime tanto que, quando rebenta, fazem um estrago que se assemelha a uma represa que a tudo suja com sua água barrenta. Por mais que se lave, que se tente, retorna ao ponto anterior do fato acontecido e fingir que nada aconteceu, as manchas e o cheiro de lodo estão lá, invisíveis para os descuidados, mas perfeitamente perceptível para quem foi por ela inundada, que tentou limpar a sujeira, tentou fingir que não aconteceu, que tentou esquecer o inesquecível.

Conforme escreveu Roland Barthes, “[d]aquilo que não mais voltará, é o odor que me volta" (BARTHES, 2003. p. 153), porque é "derivado ao cheiro, esse cheiro" (ANTUNES, 2014, p. 25) um dos principais sentidos que conduzem à memória, cheiros “dos fritos que vinham até nós e enjoava-me” (ANTUNES, 2014, p. 31).

"São quase todos velhos mais ou menos próximos da morte, solitários com tendência para o delírio, deserdados do amor, esquecidos pelos filhos que só aparecem, quando aparecem, para lhes exigir dinheiro" (SILVA, 2014). As memórias voltam aos trancos, aos solavancos, truncando suas existências, perturbando seus presentes. Todos são antigos inquilinos que vivem no passado, um passado que continua vivo: "Com uma palavra se exorcismou um passado que sob ela continuou vivo, tão vivo que só aos que 
abstractamente haviam suposto que ele morrera pode espantar a sua actual e tenebrosa ressurgência" (LOURENÇO, 1976, p.178). A memória faz ressurgir um passado que ressignifica o presente; dá um sentido diferente ao agora, a partir do vivido.

As vozes enunciadoras do romance pertencem aos moradores desses apartamentos, ou seres relacionados a eles. O que buscam esses moradores ao confessarem-se? "A memória e os relatos de memória seriam uma "cura" da alienação e da coisificação" (SARLO, 2007, p. 39). Sarlo pode ter a explicação, as palavras podem ter o sentido de cura, de redenção do passado. Ao falar, e alguns a escrever, ao expor seus fragmentos, buscam não se justificarem, mas tornarem-se pessoas, que viveram, que erraram dentro das circunstâncias que se apresentaram a eles, enfim, que foram humanas.

Falaremos dos personagens a partir da ordem em que se localizam os apartamentos onde moram: Rés do Chão Direito, Rés do Chão Esquerdo, Primeiro Direito, , Primeiro Esquerdo, Segundo Direito, Segundo Esquerdo, Terceiro Esquerdo, Terceiro Direito e, por último e talvez o mais importante, o sótão, onde vive Salazar.

4.3.1 Os personagens que vivem no Rés do Chão Direito são dois judeus, um irmão e uma irmã, sobreviventes da caçada nazista, exposto pela irmã angustiada por sonhos e lembranças do passado "enquanto cerrava a porta, dei com a neve no interior de minha infância." (ANTUNES, 2014, p. 181) e pela fuga para com o pai, a mãe e os parentes próximos. O medo não se esquece, não se deixa pelo caminho, ele abre caminho para não perder-se e ficar para trás, por isso acompanhou, invisível, sem corpo, mas mesmo assim forte, a judia até Portugal: “Tenho a certeza que anda alguém nessa casa a espiar-nos porque lhe oiço a respiração e os passos, sinto um olhar nas minhas costas e ao virar-me esconde-se, aposto que caminhonetas militares à espera, sujeitos à paisana nos portais" (ANTUNES, 2014, p. 183).

A história contada nos capítulos $5^{\circ}$ e $13^{\circ}$ pela narradora que traz o medo antigo para o presente, "vai apanhar-me, não tarda." (ANTUNES, 2014, p. 182) que mescla-se com a preocupação com o futuro, com a morte de um deles " quando o primeiro morrer o que fará o que resta" (ANTUNES, 2014, p. 185). Não carrega apenas sua memória individual, mas também as lembranças compartilhadas pelo seu um grupo social, os judeus perseguidos "as moradias em torno da nossa deserta uma a uma, espinhos em lugar de canteiro, telhados que amoleciam, uma chaminé quebrada (ANTUNES, 2014, p. 183) 
ou "um judeu de dezanove anos a quem deram um tiro no porto" (ANTUNES, 2014, p. 184). A moradora do Rés do Chão Direito não carregou apenas suas memórias individuais, pois suas memórias vinham da coletividade, de sua comunidade afetiva construída pela convivência com os cúmplices de medo e morte. No $21^{\circ}$ capítulo, a narradora, ao morrer, cede a voz ao irmão companheiro de viagem, de fuga: "A minha irmã morreu agora mesmo" (ANTUNES, 2014, p. 293). O novo narrador ainda está incrédulo por ser possível "morrer sem bombas nem tiros e tão simples" (ANTUNES, 2014, p. 293), mas continua a compartilhar as memórias da irmã e agora que ela se foi passa a escutar o medo: "aqui sozinho oiço a mobília que estala e não é a mobília" (ANTUNES, 2014, p. 293).

4.3.2 O Rés do Chão Esquerdo é o apartamento habitado por um morador que foi, no passado, torturado político durante a ditadura Salazarista, durante a qual tinha sido obrigado a escolher uma verdadeira escolha de Sofia, 2 "ou trabalhas com os traidores, ou trabalhas conosco [...] escolhi o segundo" (ANTUNES, 2014, p. 87). "A bobina do passado está em permanente rebobinação" (ROBIN, 2016, p. 25), diz Régine Robin e pega emprestada a frase de Jean-Cristophe Bailly: "Era como se o passado nevasse sobre nós" (ROBIN, 2016, p. 25). Ao rebobiná-la, o escritor caminha como uma casa em chamas, como se a neve do passado nevasse sobre ele. Os fantasmas que carrega são representantes da ditadura, das torturas que se viu obrigado a suportar e da escolha feita durante o regime militar, das lembranças de infância onde a mãe tinha sido amante do padre da paróquia local e que acabou sendo encontrado morto com própria foice no pescoço, morto, atrás da igreja, crime que foi acobertado, ou ignorado, pela Guarda: “Coisas de ciganos" (ANTUNES, 2014, p. 95). Não perdoou a mãe, acusa-a, ainda, na hora da morte: "Pôs-me no mundo não esqueço, mas pensasse nisso ao meter-se com o padre" (ANTUNES, 2014, p. 199). Os capítulos $6^{\circ}, 14^{\circ}$ e $22^{\circ}$ nos mostram, ainda, o personagem marcado por um casamento falido, de sexo raro que, “depois dos primeiros meses de casado, ficava sempre para amanhã, para a semana” (ANTUNES, 2014, p. 95). A solidão e as lembranças rondam o Rés do Chão Esquerdo e o morador escritor, que escreve um livro, que preferia ainda ouvir as censuras da esposa do que "os silêncios da ausência," (ANTUNES, 2014, p. 93) ou para acompanhá-lo ao médico e que conhecesse

\footnotetext{
${ }^{2}$ A Escolha de Sofia, romance de William Clark Styron. Em Auschwitz, Sofia é capturada com os dois filhos, Jen e Eva e, pelo fato de ser polonesa, é forçada por um soldado nazista a escolher um dos dois filhos para morrer - um para a câmara de gás e o outro poupado.
} 
os males dos quais ele padecia: "somos pouca coisa é verdade como ensinava o padre, uma mão cheia de pó, uma alma que se põe logo a andar, uma breve luzinha entre duas eternidades de escuridão" (ANTUNES, 2014, p. 199), a luzinha que a mãe queria acesa, com medo da escuridão da eternidade que a esperava após a morte por ter pecado com o padre.

\begin{abstract}
A memória, então, não é nem sensação nem julgamento, mas é um estado ou qualidade (afeição, afeto) de um deles, quando o tempo já passou. Toda memória, então, implica a passagem do tempo. Portanto só as criaturas vivas que são conscientes do tempo podem lembrar, e elas fazem isso com aquela parte que é consciente do tempo (ARISTÓTELES, 1986, p. 291).
\end{abstract}

É com essa parte da alma, a que produz imagens, que o personagem pensa e tem consciência da passagem do tempo, o tempo da memória, do antes e do depois, "o relógio sem ponteiros marcava a hora certa, isso há vinte, trinta anos e a hora certa sempre, quem afirma que o tempo avança, engana-se, somos nós que avançamos e nos tornamos idosos, não ele" (ANTUNES, 2014, p. 204), mas procura desculpas para o tempo, pois a culpa é dos homens que o percebem passar e que envelhecem ao percebê-lo e, por culpa de si mesmos, também, morrem para que a eternidade da escuridão possa iniciar o seu trabalho.

Um escritor pode fazer voltar a memória, fantasiá-la ou transmutá-la, pode trazer o esquecido no tempo e espaço de uma narrativa. "O que está proibido ao historiador, está ao alcance do romancista" (ROBIN, 2016, p. 98). Um escritor pode fazer reviver um anônimo, um esquecido, que muitas vezes deixa quase nada de si, um nome, uma profissão. Se um escritor não vier salvá-lo do anonimato, ele será completamente esquecido, como se nunca houvesse existido. "Quando não sabemos, imaginamos" (ROBIN, 2016, p. 98). O que faltar, os espaços, os vácuos, pode ser completado pela fantasia e reflexão desse escritor. "O crível, o plausível, no lugar da verdade" (ROBIN, 2016, p. 98). A imaginação pode vir a complementar os fatos, vestígios podem ser recuperados. Retalhos de uma vida podem ser resgatados e costurados e desses retalhos podem surgir uma colcha inteira. Tudo o que o escritor nos revela é verdadeiro, realmente aconteceu no passado? O narrador morador do Rés do Chão Esquerdo confidencia: "confesso que menti em várias ocasiões para embelezar acontecimentos" (ANTUNES, 2014, p. 318) e é impossível para nós, leitores, "desmaranhar o verdadeiro do falso" (ROBIN, 2016, p. 14). Das memórias do narrador, de suas lembranças descontínuas, é difícil saber se algumas dentre elas constituem fatos vividos ou contados, não há como 
diferenciá-los: "no caso de mandar eu no livro rasurava esse capítulo, mas não passo de um personagem que o autor manipula como lhe dá na gana" (ANTUNES, 2014, p. 317). Esse narrador não cede a voz narradora no último capítulo.

4.3.3 O Primeiro Direito é habitado por uma mulher gorda, atributo que ela faz questão de frisar e que lhe direciona a existência, que narra apesar de que não lhe sucediam "coisas importantes, com uma vida sexual ocasional, amante do chefe de secção por certo tempo, apegada ao padrasto, filha de um pai desconhecido:

"Se falava de meu pai a minha mãe arrependida

- Uma estupidez de minha parte" (ANTUNES, 2014, p. 96).

A narradora fala sobre si, não para convencer, mas para libertar-se: "Se ele não fala como sujeito que tem intenção de escrever uma autobiografia, não pretendia ser verdadeiro porque não fala para um leitor, mas para si mesmo, ele não precisa de crédito, não pretende se sustentar. Ele não se desenvolve buscando persuadir" (SARLO, 2007, p. 33). A moradora fala para um leitor específico que não nos apresenta, mas talvez escreva mais para compreender-se, por solidão, por ter perdido o padrasto, e por ter que cuidar do amante chefe de sessão, "veio não por amor, veio para morrer aqui" (ANTUNES, 2014, p. 322). Seria seu verdadeiro objetivo com sua escritura autoflagelar-se? Poderia ser para dizer dos seus fiapos de infância, de seus retalhos de imagens, de seus fracassos: "sou feia, engordei" (ANTUNES, 2014, p. 98). Arrepende-se de estar ali, da sua vida, de cuidar de um velho que não amava, e sente rancor do tempo que passa e que "depena o interior da gente" (ANTUNES, 2014, p. 332).

4.3.4 O morador do Primeiro Esquerdo é um bêbado que escreve suas lembranças: Assim ele descreve sua escritura: "enquanto escrevo isso vem-me à ideia a lua que não existia e o vento que se a gente falasse dispersava os discursos" (ANTUNES, 2014, p. 57). Ele escreve o que não pode ser dito. Bebeu desde novo, incentivado pelo pai, Avelino: “Bebe para espertares miúdo" (ANTUNES, 2014, p. 56). A irmã do narrador do $4^{\circ}$ e $12^{\circ}$ capítulo percebia que bebia e que ficaria como o pai, que estava se transformando em alcoólatra: “-Vais ficar um desgraçado pior que o pai e não é assunto de que me orgulhe mas fiquei sim senhor "(ANTUNES, 2014, p. 57). 
Um dia que ficou marcado na memória do narrador, o pai levou a irmã à estação de trem para que esta partisse numa viagem sem volta e sem destino e "o mundo comeua" (ANTUNES, 2014, p. 56). Assim nos conta o narrador que escreve suas lembranças:

“o marido da minha irmã devolveu-a no dia seguinte ao casamento

- Não está inteira” (ANTUNES, 2014, p. 56).

Depois desse dia houve uma mudança no íntimo do narrador: “eu que há séculos não consigo gemido nenhum, tornei-me uma pedra e no entanto sonho, acordo de cara molhada porque um comboio partiu da estação e eu a correr ao seu lado chamando a minha irmã que não se despediu de mim” (ANTUNES, 2014, p. 57).

A morte do pai e o suicídio da mãe que se atirou a um poço, uma filha morta ainda bebê no hospital, completam o quadro do morador alcoólatra que infernizava a vida dos vizinhos, da esposa e da filha Alexandra que escreve um emaranhado de lembranças e sentimentos, "em certos momentos vêm-nos ao miolo assuntos antigos que transtornam a gente" (ANTUNES, 2014, p. 63), e que por momentos fazem-no pensar ser o próprio pai. Culpava a filha Alexandra por ter sobrevivido à irmã, "não te perdoei a morte de tua irmã, culpei-te por viveres, cresceres, seres saudável” (ANTUNES, 2014, p. 176). No $20^{\circ}$ capítulo, a narração é entregue à Alexandra pelo pai que se perdeu no mundo.

4.3.5 No apartamento Segundo Direito mora Joaquim, salazarista, velho, 81 anos, marcado por um casamento arruinado que manteve com a esposa, marcado já na noite de núpcias pela admiração da mulher após o ato sexual: “- Afinal, é só isso?” (ANTUNES, 2014, p. 14,), ou comentários como “- Estou para saber como engravidei duas vezes" (ANTUNES, 2014, p. 18-19). A angústia mais marcante que entrecortam suas memórias, que perpassam os capítulos $1^{\circ}$ e $9^{\circ}$, traduz-se por: "Não sou homem, perdoa" (ANTUNES, 2014, p. 96, 127, 130, 136, 137, )

O $17^{\circ}$ capítulo é narrado pelo filho que vai ao apartamento do pai: "foi de olhos fechados que cheguei à rua da juíza [...] à entrada do prédio um bêbado" (ANTUNES, 2014, p. 263), atormentado pelas lembranças das vozes da mãe e da governanta a falarem sobre o pai: 


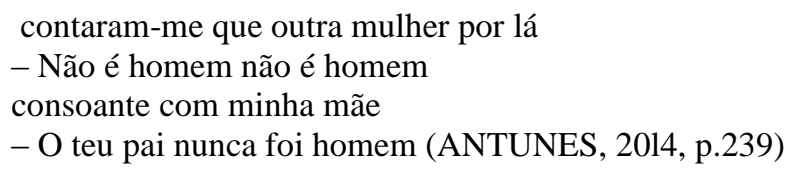

4.3.6 A rememoração da moradora do Segundo Esquerdo, Idália, é marcada pela ditadura e por lembranças de quando moça, "magrinha, a fugir da polícia" (ANTUNES, 2014, p. 31). Agora juíza, desencadeia um fluxo de memórias que quebram a linearidade temporal. Nos capítulos $2^{\circ}$ e $10^{\circ}$, por meio de flashback, o personagem volta-se confusamente para o passado e retorna ao presente para resumi-lo:

desde que foram embora, meus filhos não telefonam, não escrevem, a indiferença deles magoou-me, não me magoa já, disseram-me que meu marido se casou em Moçambique, não sei, nunca me chamou de esquilozinho gorducho, nunca me chamou fosse o que fosse e no entanto, e no entanto nada, adiante, não houve muito depois, três ou quatro, um colega meu, um senhor que encontrei no café, o homem mais moço e é tudo, iam-se embora por alturas do jantar e eu o resto das horas sozinha (ANTUNES, 2014, p. 33).

O $18^{\circ}$ capítulo é narrado pela filha da juíza, que escreve após quatro anos do falecimento da mãe.

4.3.7 O morador do Terceiro Esquerdo é Augusto, um coronel, marcado pela solidão, medo da morte e torturado pela lembrança da mulata que mandou partir, mesmo sabendo que poderia estar grávida de um filho seu, que amava, mas que não poderia manter devido ao preconceito e hierarquia da qual fazia parte. Ele narra suas memórias e descreve o presente nos capítulos 3 e 11, marcados, sobretudo pelas memórias da mulata.

O $19^{\circ}$ capítulo é narrado pela filha da mulata: "São filhos daquela preta acolá algum mulato tem pai?" (ANTUNES, 2014, p. 266), moradora da África, Lunda, “em aldeias isoladas, construções coloniais que as formigas abateram com os fantasmas dos donos nas varandas" (ANTUNES, 2014, p. 268), numa barraca ao lado da casa do pai branco". Ela teve algum estudo, pois "mesmo mulatos alguma coisa lhes há-de entrar na cabeça até os animais aprendem" (ANTUNES, 2014, p. 267).

Ela vem a Portugal para visitar o coronel "e quanto ao oficial descubro-o um dia destes, dará por mim ao chegar a casa, não previno, não escrevo" (ANTUNES, 2014, p. 275). O coronel reconhece os passos na escada, passos semelhantes ao da mulata que foi parar na África após falar-lhe da gravidez. Ele já "não pensava na África quando sentiu os passos na escada" (ANTUNES, 2014, p. 278). Se a memória é um regresso à 
consciência despertada de um episódio reconhecido como tendo sucedido antes do momento em que esta declara tê-lo sentido, percebido, sabido e a memória é uma representação das coisas já expostas anteriormente para si, uma possível reconfiguração de tais dados preservados na memória que são despertados pela rememoração. Tal relembrança exige um esforço - ars memoriae, que faz com que procuremos o conhecimento obtido anteriormente que está agora guardado na memória, o velho coronel guardava uma memória, o som de passos semelhantes, que vinham do passado, "tinha certeza de lhe serem familiares e, no entanto, a memória falhava" (ANTUNES, 2014, p. 279), lembravam-lhe os passos da mulata não esquecida.

4.3.8 No Terceiro Direito mora uma atriz de 91 anos, empobrecida, amante do ditador português que "abandonou o teatro com o desgosto da morte de Salazar" (ANTUNES, 2014, p. 226) envergonhada pela franqueza da "sobrinha" em frente ao visitante: "Já ninguém nos fia, senhora" (ANTUNES, 2014, p. 112), adoradora de Salazar "não é propaganda contra Salazar, quem consegue ter alguma coisa contra Salazar" (ANTUNES, 2014, p. 113). Ela guarda memórias de um passado de glórias que nos conta de um só fôlego, em uma sequência que aparenta não ter intervalos, fazendo confissões e misturando lembranças de glórias passadas onde recebe a proteção do presidente ditador:

“- Quer que os castigue senhora?

com a minha mão poisada na sua luva branca ultrapassando salões e salões de vénias de ministros e o Cardeal a abençoar-me" (ANTUNES, 2014, p. 114). A velha atriz guarda memórias e se vê atormentada pelas memórias da atenção que o amante da mãe queria de si “- Ao menos um carinho" (ANTUNES, 2014, p. 119). Vem-lhe perturbar a velhice as lembranças da ajuda que recebia do amante da mãe "para os teus alfinetes" (ANTUNES, 2014, p. 119) e de quando "a esposa do senhor que ajudava minha mãe veio buscá-lo com os filhos, tiraram-lhe pulseiras, broches

-“Sua ladra” (ANTUNES, 2014, p. 119). 
A memória lhe vem, no $8^{\circ}$ capítulo, trazendo a imagem da mãe sendo esbofeteada pela família desse amante: "uma bofetada em minha mãe, uma bofetada em mim" (ANTUNES, 2014, p. 121). No mesmo sopro, fala das humilhações passadas e presentes.

No $16^{\circ}$ assume o comando da narrativa a voz da moça quase feia "a minha irmã feia, eu assim, assim" (ANTUNES, 2014, p. 224) que cuida a atriz: "morar com uma velha maluca a cair da tripeça e tratá-la por tia quando anunciou

- Vou ser dama de companhia de uma atriz que foi quase esposa de Salazar." (ANTUNES, 2014, p. 223).

"Como as memórias persistem, tenho miolos de ferro velho" (ANTUNES, 2014, p. 340).

No $24^{\circ}$ capítulo, a cuidadora da atriz-voz narradora, nos revela quem é o morador do sótão:

\begin{abstract}
aquecia o resto da sopa, vagas folhinhas de hortaliças numa tigela morna, subia ao sótão em que segundo o proprietário não morava ninguém, um cubículo sujo no qual as conversas dos pombos não cessavam, empurrava a porta encostada, tornava a empurrá-la no sentido contrário, devagarinho para que nenhum protesto dos gonzos e entregava a tigela ao senhor doutor sempre de fato e gravata, sempre bem penteado, sentado num caixote vazio à minha espera, que a comia sem agradecer, na lentidão concentrada das pessoas do campo, sob os excrementos das telhas, o senhor doutor um bocadinho mais idoso que o retrato dele na parede da escola, no qual em vez de olhar-nos estudava o futuro para nós inlocalizável e para ele evidente numa serenidade absoluta, sabendo tudo, prevendo tudo, solucionando tudo, dirigindo-se a nós de longe em longe no rádio com a sua vozita quebrada, ele fingira ter morrido para melhor nos governar e continuando conosco ainda mais discreto, mais invisível, mais forte, devolvendo-me a tigela com uma sombra de sorriso

- Não estava mal a sopinha

e eu arrepiada de gratidão e orgulho, o homem acabou por me estender os melões, desculpando-se

- Percebe disto?

que diferença entre ele e o nosso presidente no sótão com o qual nem me atrevia a

- Soube-lhe bem senhor doutor?

aguardando de pé que secasse a boca no lenço retirado devagar da algibeira, não por dificuldade nos dedos, pela sua majestade natural, que honra para mim servi-lo e ainda por cima não no palácio, no sotãozito onde se escondia para melhor dirigir o País e conhecer sem intermediários que distorcem por bajulação e ampliam em proveito próprio a vida e as condições dos portugueses (ANTUNES, 2014, p. 339)
\end{abstract}

\title{
4.3.9 O sótão e seu morador-personagem
}

"Se Salazar sonhasse resolvia o assunto em menos de um fósforo, mas o que sonham os mortos"

(ANTUNES, 2014, p. 230) 
Salazar não está morto, sua presença permanece na memória dos moradores do romance Caminho como uma casa em chamas. "Além do sótão supostamente vazio (mas que, de facto, é habitado por um morador que continua a assombrar esta 'casa portuguesa"” (FERNANDES, 2015, p. 173). A personagem do Primeiro direito dá-nos indícios de Salazar ser o morador do sótão: “dizem que Salazar não morreu, se esconde por aí, continuando a mandar" (ANTUNES, 2014, p. 318) e logo fala do morador do sótão: "ia apostar que mora alguém no sótão que me garantiram decerto porque a meio da noite pessoas, posso não ter mais qualidade alguma, mas nasci com orelhas de tísica" (ANTUNES, 2014, p. 324). A mulher que cuida a atriz do Terceiro Direito narra a existência do morador, de Salazar que ali estava para resolver os problemas de Portugal, que "se inclui a figura arruinada de Salazar. Simulacro do Portugal onde estes inquilinos cresceram, este fantasma materializa-se no sótão, "não [como] uma pessoa, [como] a presença atenuada de uma autoridade extinta" (FERNANDES, 2015, p. 174). No sótão vive um morador como se fosse o telhado do edifício construído por António Lobo, representativo de Portugal e que continua a assombrá-lo: "se calhar não terão o mesmo fim, caminharei pelos séculos dos séculos como uma casa em chamas regulando o país" (FERNANDES, 2015, p. 350). O morador do sótão insiste em reiterar: "Sou eu quem manda, mas mando em quê" (ANTUNES, 2014, p. 352). Salazar, mesmo cansado, tem saudades do poder, "tenho saudades de me contrariarem, me ralharem, tomarem conta de mim.” (ANTUNES, 2014, p. 350). Ainda assim escuta amiúde as ovações do povo: “Salazar, Salazar, Salazar!” (ANTUNES, 2014, p. 354).

Salazar vivo representa uma anulação da Revolução dos Cravos que depôs o regime ditatorial do Estado Novo:

\footnotetext{
Supor que um Salazar roto sobrevive clandestinamente numa mansarda é equivalente a conjecturar que o " 25 de Abril não libertou os corpos, senão formalmente, como não alargou o horizonte dos espíritos, senão teoricamente". Por outras palavras, o "espaço dos corpos" continua "encolhido e enquistado pelo medo e [pelos] hábitos de submissão interiorizados durante décadas" (FERNANDES, 2015, p. 175).
}

A presença de Salazar, suas memórias emaranhadas às memórias dos moradores do prédio, pretende mostrar que sua presença ainda é coeva, que demorarão a apagaremse os traços e rastros das memórias da ditadura e falar das marcas deixadas no povo português. 


\section{Conclusão}

Em Caminho como uma casa em chamas, a memória perpassa os personagens de António Lobo Antunes, representativa de momentos vividos pelos sujeitos, momentos individuais, coletivos e até mesmo históricos. Presos ao passado, percebem, em alguns rasgos de lucidez, que estão no momento presente, num agora profundamente marcado pelo passado, tentando resgatar o que se foi, ou pelo menos justificar esse passado instalado no presente e que não pretende afastar-se. O prédio é um espaço de memórias que não aspiram, nem podem, ser tomadas como portadoras da verdade; são memórias enquanto construção afetiva, confusas, nada cronológicas. Até o final não se pode ter certeza de que, ao interrogar ao passado, a verdade da memória à qual se refere Ricoeur, vem aos moradores, ou se a imaginação desempenha um papel importante nessa construção meio que onírica, nem se a memória é autêntica ou equivocada. Percebem-se, neles, dificuldades de estabelecer um total reconhecimento do passado, que retorna eivado de perturbações e culpas. Os moradores cercam-se de suas memórias que vêm preencher o espaço vazio, como quem se cerca de amigos, dialogam com elas, se debatem, tentam compreendê-las; as memórias são fantasmas que os assombram, que os explicam, que lhes fazem companhia. É necessário, a esses moradores, tecer essas imagens, sugálas desse emergir de memórias, ora precisas, detalhadas; ora dúbias, difusas, que passam uma relação de continuidade entre o passado e presente. Como se estivessem diante da morte, os moradores do edifício veem cenas de suas vidas, seus acertos, mas principalmente seus erros, entretanto, sem o mea culpa que alivia; justificam-se, mas não encontram a consolação, nem o conforto. Ao não conseguirem eximir-se, não se isentam nem expiam.

Entre esses delírios dos personagens, misturando presente e passado, um ser sobrepõe-se a tudo, o morador do sótão, que simbolicamente, mora acima de todos, no alto do edifício, no alto de suas vidas, comandando as ações, as memórias, os pensamentos e os fantasmas, já que Salazar continua, em forma de espectro, a governar Portugal e seus moradores. Sendo um fantasma que assombra a vida dos moradores de Caminho como uma casa em chamas, Salazar não deixa de ser ele próprio um fantasma que assombra e que é assombrado por seus próprios fantasmas. António Lobo conseguiu representar, em seu mundo ficcional, em seu prédio habitado por moradores assombrados pelo passado, um Portugal ardendo em agonias, preso em suas memórias, suas amarras, 
desejoso de se libertar, mas imerso em recordações de tempos que ainda não se foram totalmente, que jazem no fundo de suas mentes, latentes, latejantes, conduzido por uma assombração que os dirige a todos, mesmo que ele próprio não saiba como continuar seu caminho, pois arde como uma casa em chamas.

A escritura é inconclusa, pois a memória dos moradores é retomada, passada a outros personagens, os das memórias, que chegam para continuar as memórias dos velhos, as retomam e continuam para evitar que elas caiam em esquecimento; em um esforço dirigido contra o esquecimento.

\section{Referências}

ANTUNES, António Lobo. Caminho como uma casa em chamas. Lisboa: Dom Quixote, 2014.

ANTUNES, António Lobo. Entrevista. Disponível em: http://visao.sapo.pt/opiniao/opiniao_antonioloboantunes/caminho-como-uma-casa-emchamas $=\mathrm{f} 647927$

ANTUNES, António Lobo. Receita para me lerem. In: ANTUNES, António Lobo. Segundo livro de crónicas. Alfragide: D. Quixote. 2007.

ANTUNES, António Lobo. Biografia. Biblioteca. Disponível em: http://www.alpiarca.pt/biblioteca/pdf/lobo_antunes.pdf

ANTUNES, António Lobo. Biografia. Boletim Bibliográfico da Biblioteca da Escola Secundária Rainha Dona Amélia: O escritor do mês - A breve eternidade das palavras. outubro de 2014.Disponível em https://pt.scribd.com/document/243197365/AntonioLobo-Antunes-pdf.

ARISTÓTELES. Da memória e da reminiscência. On the soul - parva naturalia - on breath. Harvard University Press, Cambridge, Mass.1986.

BARTHES, Roland. Roland Barthes por Roland Barthes. São Paulo: Estação Liberdade, 2003.

BYLAARDT, Cid Ottoni. Caminho como uma casa em chamas. Scripta, Belo Horizonte, v. 21, n. 42, p. 301-304, 2017

FERNANDES, Evelyn Blaut. A ficção de António Lobo Antunes da coreografia dos espectros à caligrafia dos afectos. 2015. Disponível em:

https://estudogeral.sib.uc.pt/bitstream/10316/28158/3/A\%20fic\%C3\%A7\%C3\%A3o\%2 0de\%20Ant\%C3\%B3nio\%20Lobo\%20Antunes.pdf.

LOURENÇO, Eduardo. O fascismo nunca existiu. Lisboa, Dom Quixote, 1976.

MENÉNDEZ, Fernanda Miranda. Salazar ou a conquista discursiva do poder. Disponível em: http://www.ufjf.br/revistaveredas/files/2009/12/artigo111.pdf. 
PLATÃO. Fédon. In: PLATÃO. Diálogos: Fédon - Sofista - Político. Ediouro, s/d.

RICOEUR, Paul. A memória, a história, o esquecimento. Campinas (SP): Unicamp, 2007

ROBIN, Régine. A memória saturada. Campinas (SP): Unicamp, 2016.

SARLO, Beatriz. Cultura da memória e guinada subjetiva. São Paulo: Companhia das Letras; Belo Horizonte: UFMG, 2007.

SILVA, José Mário. Um remexer no escuro. Texto publicado no suplemento Actual, do semanário Expresso, 15 de novembro de 2014, disponível em http://alaptla.blogspot.pt.

SILVA, Maria Augusta. António Lobo Antunes Entrevistado por. Disponível em: http://www.casaldasletras.com/maria_Grandes\%20Entrevistas.html., 2010. 